\title{
OS STANDARDS PROBATÓRIOS E A BUSCA DE MAIOR OBJETIVIDADE NA DECISÃO SOBRE OS FATOS ${ }^{1}{ }^{2}$
}

\section{THE STANDARDS OF PROOF AND THE SEARCH FOR MORE OBJECTIVITY IN THE DECISION ABOUT THE FACTS}

Ravi Peixoto

Doutor em direito processual pela UERJ. Mestre em Direito pela UFPE. Membro da Associação Norte e Nordeste de Professores de Processo (ANNEP), do Centro de Estudos Avançados de Processo (CEAPRO), da Associação Brasileira de Direito Processual (ABDPRO) e do Instituto Brasileiro de Direito Processual (IBDP). Procurador do Município do Recife. Advogado. Recife/PE. E-mail: ravipeixoto@gmail.com

RESUMO: O artigo tem por objetivo destrinchar o conceito de standard probatório, inserindo-o adequadamente no contexto do procedimento decisório, apresentando as suas principais funções e identificando sua aptidão para tornar mais objetiva a decisão sobre os fatos no processo decisório.

PALAVRAS-CHAVE: Direito probatório. Decisão sobre os fatos. Standard de prova.

\begin{abstract}
The article aims to untangle the concept of standard of proof, properly inserting it in the context of decision-making, presenting its main functions and identifying its ability to make the decision on the facts in the decision process more objective.
\end{abstract}

KEYWORDS: Law of evidence. Decision on the facts. Standard of proof.

\footnotetext{
${ }^{1}$ Artigo recebido em 21/02/2021 e aprovado em 07/04/2021.

${ }^{2}$ Esse artigo tem por base a seguinte obra, que aprofunda o tema: PEIXOTO, Ravi. Standards probatórios no direito processual brasileiro. Salvador: Juspodivm, 2021.
} 
Revista Eletrônica de Direito Processual - REDP.

Rio de Janeiro. Ano 15. Volume 22. Número 2. Maio a Agosto de 2021

Periódico Quadrimestral da Pós-Graduação Stricto Sensu em Direito Processual da UERJ

Patrono: José Carlos Barbosa Moreira (in mem.). ISSN 1982-7636. pp. 586-618

www.redp.uerj.br

\section{Introdução}

O direito probatório, em especial o raciocínio probatório, no contexto brasileiro consiste em uma área de estudo que não foi tradicionalmente objeto de muitas obras específicas, nem de grandes preocupações doutrinárias. Não obstante a problemática da fundamentação jurídica seja riquíssima em estudos, ${ }^{3} \mathrm{o}$ mesmo não acontece em relação à justificação dos fatos. ${ }^{4}$ Apenas nos últimos anos, talvez até pela influência de um interesse crescente em outros países do civil law sobre o tema, ${ }^{5}$ começa a surgir alguma reflexão doutrinária sobre a justificação dos fatos.

No direito probatório há um tema que sofre de uma carência ainda maior de estudos específicos, que são os standards (ou estândares) ${ }^{6}$ probatórios, que, embora receba bastante atenção no common law e com crescente aumento da utilização em países do civil law, inclusive com previsão legislativa na Itália, Espanha e Colômbia, mantém-se um tema

\footnotetext{
${ }^{3}$ Apenas a título exemplificativo, existem diversas obras sobre o tema, mas cujo foco não são as decisões sobre os fatos, mas a interpretação jurídica e o tema dos precedentes: NOJIRI, Sérgio. O dever de fundamentar as decisões judiciais. São Paulo: RT, 1998; SILVA, Beclaute Oliveira. A garantia fundamental à motivação da decisão judicial. Salvador: Juspodivm, 2007; MOTTA, Cristina Reindolff da. A motivação das decisões cíveis. Porto Alegre: Livraria do Advogado, 2012; STRECK, Lenio Luiz. O que é isto - decido conforme minha consciência? Porto Alegre: Livraria do Advogado, 2012; ABBOUD, Georges. Discricionariedade administrativa e judicial. São Paulo: RT, 2014; LUCCA, Rodrigo Ramina de. O dever de motivação das decisões judiciais. Salvador: Juspodivm, 2015; SCHMITZ, Leonardo Ziesemer. Fundamentação das decisões judiciais. São Paulo: RT, 2015. Mesmo quando a decisão sobre os fatos é analisada, aparece apenas como um elemento secundário: PEREIRA, Carlos Frederico Bastos. Fundamentação das decisões judiciais. São Paulo: RT, 2019, p. 147-155.

${ }^{4}$ Também destacando a falta de reflexão doutrinária sobre o tema da decisão sobre os fatos: FERRER BELTRÁN, Jordi. Prueba y verdad en el derecho. $2^{\mathrm{a}}$ ed. Madri: Marcial Pons, 2005, p. 15-16; POLI, Roberto. Standard of proof in Italy. . In: TICHÝ, Luboš (ed.). Standard of proof in Europe. Tübingen: Mohr Siebeck, 2019, p. 197.

${ }^{5}$ Cf. a título exemplificativo: FERRER BELTRÁN, Jordi. La valoración racional de la prueba. Madri: Marcial Pons, 2007; NIEVA FENOLL, Jordi. La valoración racional de la prueba. Madri: Marcial Pons, 2010; ABEL LLUCH, Xavier. La valoración de la prueba en el proceso civil. Madri: La Ley, 2014.

${ }^{6} \mathrm{Na}$ língua portuguesa, o equivalente para o termo standard é estândar, mas que é pouco utilizado pela doutrina, que acabou por consagrar a nomenclatura em inglês. Até onde se tem conhecimento, apenas um autor utiliza a nomenclatura em português (MIRANDA NETTO, Fernando Gama de. Ônus da prova no direito processual público. Rio de Janeiro: Lumen Juris, 2009; MIRANDA NETTO, Fernando Gama de; LEAL, Stela Tannure; SOUZA, Thiago Serrano P. Responsabilidade Civil em virtude de doenças associadas ao tabagismo. Revista Científica Virtual da ESA, v. 17, 2014). Consta ainda a nomenclatura em português utilizada por Danilo Knijnik que é "modelo de constatação", (KNIJNIK, Danilo. A prova nos juízos cível, penal e tributário. Rio de Janeiro: Forense, 2007, p. 2) mas que acaba por não representar adequadamente o instituto. Tem-se, aqui, uma fase da valoração probatória que visa verificar o atingimento de um patamar mínimo de exigência probatória, o que não vem representado adequadamente pela nomenclatura de modelo de constatação. Por tais motivos, haverá a utilização da nomenclatura original, em inglês (standard), já consagrada pela doutrina, bem como da nomenclatura em português (estândar).
} 
de pouca preocupação no direito processual brasileiro, em especial, no direito processual civil.

Na decisão sobre os fatos, para além da valoração das provas, há um momento posterior e indispensável da decisão relativo à seguinte verificação: se, uma vez avaliadas as provas, elas atingem um nível mínimo de suficiência para que se possa ter como provada uma hipótese fática.

O standard de prova é um instrumento de distribuição dos riscos de erros sobre a decisão dos fatos, por exemplo, uma falsa condenação (falso positivo) ou uma falsa absolvição (falso negativo), na decisão condenatória penal. Cabe a cada ordenamento jurídico, a partir da valoração dos bens jurídicos em jogo, aumentar ou diminuir a exigência probatória, alterando a probabilidade dos riscos de erros. No penal, por exemplo, com o aumento do standard de prova, a tendência será a de dificultar a condenação dos acusados e a ocorrência da falsa condenação.

Essa suficiência mínima é o patamar fixado pelos estândares probatórios e, inexistindo uma expressa corroboração exigida pelo direito, passa a ser possível que cada juiz fixe seus próprios estândares, a partir de seus próprios valores e concepções do direito. Em outros termos, a suficiência da prova será atingida quando o juiz considerar que ela foi alcançada segundo a sua própria concepção, ${ }^{7}$ face a ausência de um critério externo que indique esse patamar.

A decisão, relativa ao preenchimento do standard probatório, passa a pertencer a um campo de ampla discricionariedade de cada juiz, de difícil controle intersubjetivo. ${ }^{8}$ Essa situação ocorre porque, se o estândar probatório não precisa estar expresso na decisão, ele será utilizado de forma implícita pelo julgador, que não precisará indicar e nem justificar qual foi a suficiência probatória utilizada. Trata-se de um contrassenso em um contexto no qual há cada vez uma maior exigência de justificação e controle das decisões judiciais, a exemplo das exigências do art. $489, \S 1^{\circ}$, do $\mathrm{CPC}$ e do art. $315, \S 2^{\circ}$, do CPP, com a redação dada pela Lei 13.964/2019.

\footnotetext{
${ }^{7}$ Destacando os problemas dessa situação tautológica: VIALE DE GIL, Paula A.. ¿La prueba es suficiente cuando es suficiente? Aproximación a la construcción de la decisión de suficiencia de la prueba en materia penal Revista Pensar em Derecho, n. 4, 2014, disponível em: http://www.derecho.uba.ar/publicaciones/pensaren-derecho/revista-4.php, acessado em 29 de dezembro de 2019.

${ }^{8}$ De forma semelhante: FERRER BELTRÁN, Jordi; TUZET, Giovanni. Sulla necessità degli standard di prova per la giustificazione delle decisioni giudiziali. Diritto \& Questione Pubbliche, n. 2, dez.-2018, p. 456-457.
} 
Apesar disso, o direito positivo, a doutrina e a jurisprudência, em geral, ignoram o problema ${ }^{9}$ e, mesmo na maioria das situações em que há menção aos standards de prova, há uma ausência de sistematização ou apenas uma importação acrítica dos conceitos existentes no direito estrangeiro, a exemplo do que parece ocorrer na sua utilização ocasional pelo Supremo Tribunal Federal (STF). ${ }^{10}$

Por isso, afigura-se importante analisar de forma aprofundada exatamente o que significa o standard probatório, inserindo-o adequadamente no contexto da decisão probatória, bem como identificar a sua aptidão para objetivar a decisão sobre os fatos no processo decisório.

\section{Conceito de estândar probatório}

O estândar probatório deve ser compreendido como o grau de suficiência probatória mínima exigida pelo direito, para que uma hipótese fática possa ser considerada provada. A título exemplificativo, se o estândar probatório consiste na preponderância da prova, a hipótese fática deve, no mínimo, atingir esse grau de suficiência para que seja tida como provada.

Essa é uma exigência mínima para a hipótese fática ser considerada provada. Não significa que, em uma demanda cível, exigindo-se o standard da preponderância da prova, não possa ser atingido patamar mais exigente, como a prova acima de toda dúvida razoável. Portanto, o grau de corroboração mínimo pode ser ultrapassado, mas tem que ser alcançado para que a hipótese fática possa ser tida como provada.

O tema dos estândares probatórios não é exclusivo do direito. Trata-se de tema relevante para além do direito, atuando em diversas áreas do conhecimento. ${ }^{11}$ Em qualquer situação na qual a decisão seja proferida em condições de incerteza fática, a existência de um standard probatório aparece como um fator de redução de complexidade, por haver a inserção de quais os critérios exigidos para que uma determinada hipótese fática seja

\footnotetext{
${ }^{9}$ Destacando esse problema, cf.: KNIJNIK, Danilo. A prova nos juízos cível, penal e tributário... cit., p. 32.

${ }^{10}$ PEIXOTO, Ravi. Standards probatórios no direito processual brasileiro... cit., p. 243-249.

${ }^{11}$ LOEVINGER, Lee. Standards of proof in Science and law. Jurimetrics, v. 32, n. 32, 1992, p. 331-332; LAUDAN, Larry. Verdad, error y proceso penal: un ensayo sobre epistemología jurídica. Tradução de Carmen Vázquez e Edgar Aguilera. Madri: Marcial Pons, 2013, p. 104.
} 
considerada provada. É curioso observar que o tema dos standards probatórios seja ainda consideravelmente incipiente no civil law, ${ }^{12}$ com destaque para o quase vazio legislativo encontrado no direito brasileiro.

É importante destacar que a força probatória necessária para que se considere que um indivíduo esteja agindo de forma justificada e racional depende do contexto no qual esteja envolvido. ${ }^{13}$ Decisões que são menos importantes e trazem menos riscos exigem menor força probatória; decisões mais importantes, com maiores consequências no caso de um erro, exigem maior força probatória.

Na vida cotidiana, por exemplo, é possível falar na decisão de comprar um carro, de se casar com alguém. É possível até falar em variação de estândares, a exemplo da decisão de ir a um encontro com alguém, de iniciar um relacionamento, noivar e eventualmente se casar. O grau de confiabilidade das provas necessárias para cada uma das decisões é mais exigente do que a anterior, por requerer um maior comprometimento. Um erro na escolha da pessoa com a qual se aceita ir a um encontro tem poucas consequências, mas uma escolha errônea na realização de um casamento pode trazer consequências drásticas, tendo em vista a necessidade de partilha de bens, a guarda dos filhos e mesmo dos animais de estimação.

Uma mesma decisão pode depender de uma maior exigência probatória a depender do contexto. Tenha por base a seguinte informação: Carlos pretende viajar de ônibus de João Pessoa a Recife, e a passagem pode ser adquirida no próprio veículo.

Contexto 1: Trata-se apenas de uma viagem a passeio, para encontrar um amigo. Carlos, ao chegar à estação rodoviária, pergunta a um passageiro se aquele ônibus específico vai até Recife e se ele chega até as 14 horas, sendo a sua resposta: "acredito que sim".

Contexto 2: Carlos apresentará a sua tese de doutorado às 15 horas, na Faculdade de Direito do Recife. Ao chegar à estação de ônibus, questiona a um passageiro, que lhe dá a mesma resposta anterior.

\footnotetext{
${ }^{12}$ VÁZQUEZ, Carmen. A modo de presentación. In: VÁZQUEZ, Carmen (coord). Estandáres de prueba y prueba científica - ensayos de epistemología jurídica. Madri: Marcial Pons, 2013, p. 13. Kevin M. Clermont defende que o standard no civil law seria a íntima convicção, o que é um equívoco, eis que não se trata de um standard, mas de um modelo relativo à valoração da prova que não faz referência à força probatória da evidência, mas que não invalida a análise história do desinteresse do tema nos países do civil law: CLERMONT, Kevin M. Standards of decision in Law. Carolina do Norte: Carolina Academic Press, 2013, p. 221-272.

${ }^{13}$ FANTL, Jeremy; MCGRATH, Matthew. Evidence, pragmatics and justification. The Philosophical Review, v. 111, n. 1 , jan.-2002.
} 
No contexto 1, a resposta obtida é satisfatória para que Carlos tenha provas suficientes para decidir ingressar no ônibus. Se por acaso, o ônibus atrasar - pois faz várias paradas - ou mesmo, por algum motivo, não passar por Recife, ele irá chegar mais tarde à cidade, sem maiores consequências. No contexto 2, com as mesmas informações, a decisão de entrar naquele ônibus não alcançou uma suficiência probatória, ou seja, a sua crença justificada de que o ônibus chegará em horário adequado para que possa apresentar sua tese de doutorado não está justificada. Haveria necessidade de se informar melhor, buscando um funcionário que possa lhe fornecer informações mais precisas.

Tais considerações são importantes para que se compreenda que o estândar probatório é um conceito que exige um grau de corroboração mínimo da hipótese fática para que ela seja considerada provada; esse grau mínimo varia conforme o contexto. No caso do Direito, a variação ocorre de acordo com a regulação do direito aplicável, que pode impor uma maior ou uma menor exigência probatória.

\section{A adequada inserção dos standards probatórios no procedimento probatório}

O procedimento probatório é formado por diversas fases: a) proposição da prova $;{ }^{14}$ b) admissibilidade das provas, momento no qual haverá a decisão acerca de quais provas serão admitidas no processo; c) produção das provas, a qual se afigura relevante especialmente para aquelas provas que serão produzidas no decorrer do processo, a exemplos da prova pericial e da prova testemunhal; d) avaliação da prova; e) decisão sobre a prova.

$\mathrm{Na}$ fase de avaliação da prova, além de analisar especificamente as provas produzidas, bem como eventual ilicitude probatória, o julgador deverá verificar o apoio empírico de cada um dos fatos principais, em uma análise individualizada, como das hipóteses fáticas construídas pelos sujeitos processuais no decorrer do processo, ${ }^{15}$ de forma a verificar aquela com maior grau de corroboração com base nas provas disponíveis.

Uma vez havendo o reconhecimento, pelo juiz, de que uma determinada hipótese possui maior corroboração probatória do que as demais, tem-se o momento da decisão. Nessa

\footnotetext{
14 A fase específica de requerimento de produção da prova ocorre quando proposta pelas partes, sendo dispensada quando produzida de ofício pelo magistrado (art. 370, CPC). Nesse sentido: SANTOS, Moacyr Amaral. Comentários ao código de processo civil. $6^{\mathrm{a}}$ ed. Rio de Janeiro: Forense, 1994, v. IV, p. 7.

${ }^{15}$ Importante destacar que, no contexto do civil law, embora isso não esteja, em tese, vedado no common law, é comum que a hipótese fática eventualmente tida como provada seja construída pelo próprio magistrado.
} 
fase, deverá ser realizada a avaliação relativa à identificação acerca da hipótese fática $h$, tida como a melhor dentre as disponíveis, decidindo se ela pode, ou não, ser considerada provada, de acordo com grau de corroboração exigido pelo direito. Cada ordenamento jurídico tem aptidão para decidir o standard probatório exigido, atuando como uma regra de decisão.

Impõe-se ressaltar a necessária diferenciação entre estes momentos: a valoração das provas e o momento de tomada da decisão. No primeiro deles, o juiz irá verificar o grau de corroboração das hipóteses disponíveis e, no segundo, se a hipótese adotada atinge o standard probatório exigido. ${ }^{16} \mathrm{O}$ estândar probatório apenas atua no segundo momento, sendo a suficiência probatória mínima exigida pelo direito para que uma determinada hipótese possa ser considerada como provada, evitando que seja aplicada a regra do ônus da prova.

\section{Standards de prova e ônus da prova}

A regra do ônus da prova não deve ser confundida com os estândares probatórios. O ônus da prova consiste em regra que, em sua concepção objetiva, tem por função evitar o non liquet, por indicar ao juiz quem deve sofrer o julgamento desfavorável em caso de não preenchimento do ônus da prova. Importante que se compreenda que o ônus da prova é uma regra de julgamento que atua na insuficiência de provas.

O problema é que o ônus da prova, de forma isolada, não indica a suficiência probatória necessária para a desincumbência dos encargos probatórios, pois ela apenas aponta a quem incumbe o ônus da prova sobre determinados fatos (art. 373, CPC). Em outros termos, mesmo que a regra do ônus da prova só precise ser aplicada em caso de insuficiência de provas, ela, por si só, não indica qual o patamar necessário para que a hipótese fática possa ser tida como insuficientemente provada.

O estândar probatório atua para preencher esse vácuo normativo, que consiste na suficiência necessária para que uma hipótese fática seja considerada provada e,

\footnotetext{
${ }^{16}$ FERRER BELTRÁN, Jordi. La prueba es libertad, pero no tanto: una teoria de la prueba cuasibenthamiana. In: VÁZQUEZ, Carmen (coord). Estandáres de prueba y prueba científica - ensayos de epistemología jurídica. Madri: Marcial Pons, 2013, p. 28. No mesmo sentido: ACCATINO, Daniela. Certezas, dudas e propuestas en torno al estándar de la prueba penal. Revista de Derecho de la Pontifícia Universidad Católica de Valparaíso, v. XXXVII, jul./dez.-2011, p. 485; UBERTIS, Giulio. Fatto, prova e verità (alla luce del principio dell'oltre ogni ragionevole dubbio). Criminalia, 2009, p. 328.
} 
consequentemente, haja a desincumbência do ônus da prova. Com a indicação de uma específica suficiência probatória, passa a ser possível identificar quando a regra do ônus da prova deve ser aplicada, permitindo que se tenha conhecimento do patamar necessário para que não haja insuficiência probatória.

Assim, a regra do standard de prova é anterior à do ônus da prova, pois estabelece o grau mínimo de corroboração exigido pelo direito para que uma hipótese fática seja tida como provada. Em não sendo satisfeito esse grau, passa a ser necessária a incidência da regra do ônus da prova para poder decidir. ${ }^{17}$

Os dois institutos se completam, embora não se confundam: o estândar probatório indica quando é atingida a suficiência probatória e, por consequência, quando é desnecessária a incidência da regra do ônus da prova; o ônus da prova indica quem sofre o julgamento desfavorável em caso de não desincumbência do encargo probatório. Em outros termos, o estândar de prova permite que se verifique se houve ou não a desincumbência do ônus da prova. ${ }^{18}$ Portanto, é possível afirmar que o ônus da prova é uma regra de julgamento que, sem a presença do standard probatório, não possui um mecanismo adequado para a verificação da sua desincumbência.

\section{Valoração da prova e estândar de prova}

Ultrapassada a relação entre ônus e estândar de prova, afirma-se que os momentos de avaliação da prova e da tomada de decisão sobre a questão fática são necessários e interdependentes. Isso ocorre porque: i) para que o estândar probatório seja aplicado, é necessária a prévia avaliação da prova e ii) para que haja decisão sobre as hipóteses probatórias, impõe-se a existência de um standard, do contrário não seria possível ter conhecimento do grau de suficiência das provas para a realização do julgamento. ${ }^{19}$

\footnotetext{
${ }^{17}$ MELIM, Mafalda. Standards de prova e grau de convicção do julgador. Revista de concorrência e regulação, n. 16, out./dez.-2013, p. 147.

${ }^{18}$ Com raciocínio semelhante, cf.: SCHWEIZER, Mark. Standard of proof as decision threshold. In: TICHÝ, Luboš (ed.). Standard of proof in Europe. Tübingen: Mohr Siebeck, 2019, p. 20-21; SILVEIRA, Daniel Coutinho da. Prova, argumento e decisão: critérios de suficiência para orientação dos juízos de fato no direito processual brasileiro. Dissertação de Mestrado. São Paulo: USP, 2011, p. 281.

${ }^{19}$ TUZET, Giovanni. Assessment criteria or standards of proof? An effort in clarification. Artificial Intelligence and Law, out.-2018, p. 4. De certa forma, esta é a mesma conclusão de Accatino, ao afirmar que "para decidir en forma justificada si está o no está probada en un proceso una determinada proposición sobre los hechos del caso es necesario, en un sistema de libre valoración probatoria, contar com un estándar para evaluar si las
} 
Nos países que não adotam standards probatórios específicos, em caso de utilização do modelo de valoração do livre convencimento motivado, a ausência do standard torna o sistema falho em termos de controle, afinal, inexiste a fase em que o juiz deve verificar se a valoração realizada atinge o grau mínimo exigido pelo direito, ${ }^{20}$ diminuindo a eficácia de direitos fundamentais como a presunção de inocência e o dever de justificação das decisões.

Afinal, se o direito não aponta um standard exigido para a prolação da decisão, é mais difícil o controle acerca da suficiência probatória. ${ }^{21}$ Isso ocorre porque essa suficiência probatória será definida pelo próprio juiz, estando muitas vezes implícita, caso o ordenamento jurídico não exija qualquer menção à questão. Como o estândar probatório não é expressamente exigido pelo direito, incumbe ao juiz escolher qual a suficiência de prova necessária e a eventual impugnação terá, muitas vezes, que adivinhar qual a escolhida pelo magistrado. De certa forma, em não sendo o standard probatório um elemento obrigatório da decisão, a possibilidade de controle pelas partes será limitada à própria valoração da prova, pois a decisão sobre o estândar estará implícita, limitando-se o juiz a afirmar que há prova suficiente ou que está convencido.

A persuasão racional ou o livre convencimento motivado, adotado pelo direito processual brasileiro, deve ser compreendido como os critérios racionais para que se possa identificar qual a hipótese mais provável dentre as hipóteses fáticas concorrentes a partir dos elementos probatórios disponíveis. Por sua vez, o standard probatório atua no sentido de indicar o grau de suficiência necessária para que a hipótese fática seja considerada provada.

Os critérios de valoração de prova atuam em relação às inferências probatórias para identificar o seu grau de confirmação. Por outro lado, o standard de prova visa a responder à questão se o grau atingido é suficiente para uma tomada de decisão; trata-se,

pruebas disponibles, valoradas racionalmente, son suficientes para considerarla probada". (ACCATINO, Daniela. Certezas, dudas e propuestas en torno al estándar de la prueba penal... cit., p. 484).

${ }^{20}$ Com a mesma preocupação: LAUDAN, Larry. Is it finally time to put "proof beyond reasonable doubt" out to pasture? The Routledge Companion to Philosophy of Law Routledge, 21 de março de 2012, disponível em: https://www.routledgehandbooks.com/doi/10.4324/9780203124352.ch21, acessado em 12 de novembro de 2019, p. 317; ARAYA NOVOA, Marcela Paz. El controle ex post de la calidad de los enunciados probatorios en materia penal en Chile. De la epistemología a la praxis. Tese de Doutorado. Girona: Universidade de Girona, 2016, p. 282; FERRER BELTRÁN, Jordi. Sobre el deber de motivación de las decisiones probatorias y el juicio por jurados. La sentencia V.R.P., V.P.C. y otros vs. Nicaragua de la corte IDH. Quaestio facti. Revista Internacional sobre Razonamiento Probatorio, v. 1, 2020, p. 377.

${ }^{21}$ FERRER BELTRÁN, Jordi; TUZET, Giovanni. Sulla necessità degli standard di prova per la giustificazione delle decisioni giudiziali. Diritto \& Questione Pubbliche, n. 2, dez.-2018, p. 456-457. 
então, de uma regra de decisão. O primeiro é invariável, sendo os critérios para valorar uma prova independentes do direito material, já o estândar é variável a depender do tipo de fato típico concreto. ${ }^{22}$

É importante a diferenciação entre esses dois momentos.

Caso o momento de verificação do preenchimento do standard seja ignorado, resta apenas a valoração da prova, mas sem que haja um indicativo da suficiência mínima a ser atingido. Se o magistrado não possui uma orientação, por parte do ordenamento jurídico, acerca do estândar probatório, a verificação do preenchimento do ônus da prova se torna uma decisão bastante discricionária, pois ele será preenchido quando atingido um nível probatório que será escolhido por cada juiz. Em sendo exigido o preenchimento do ônus da prova para que uma determinada decisão seja prolatada, é importante que o ordenamento jurídico indique o grau necessário de suficiência das provas.

No entanto, é inegável que há uma afinidade entre os critérios de avaliação probatória e os standards probatórios, uma vez que alguns standards incorporam elementos de avaliação probatória e vice-versa, especialmente quando em um determinado ordenamento jurídico apenas um desses elementos é devidamente definido. ${ }^{23}$

De fato, para que o sistema seja coerente, um modelo objetivo de valoração da prova deve ser acompanhado por um standard probatório igualmente objetivo. Como destaca Dei Vecchi, há uma interdependência entre a valoração da prova e a suficiência probatória, uma vez que, se é o sistema de valoração que determina os critérios para a aceitação de enunciados fáticos como provados, o standard de prova deve ser formulado de forma a atualizar o sistema de valoração, fornecendo-lhe material para que se possa decidir quando a hipótese fática está provada. ${ }^{24}$ Se há descompasso entre o standard de prova e o sistema de valoração, tem-se um sistema incoerente e disfuncional.

22 GONZÁLEZ LAGIER, Daniel. ¿Es posible formular un estándar de prueba preciso y objetivo? Algunas dudas desde un enfoque argumentativo de la prueba. Disponível em: https://www.academia.edu/37549075/_Es_posible_formular_un_est\%C3\%A1ndar_de_prueba_preciso_y_obj etivo_Algunas_dudas_desde_un_enfoque_argumentativo_de_la_prueba, acessado em 22 de novembro de 2019 , p. 9.

${ }^{23}$ TUZET, Giovanni. Assessment criteria or standards of proof? An effort in clarification... cit., p. 3, 14-15.

${ }^{24}$ DEI VECCHI, Diego. Estándares de suficiencia probatoria, moralidad política y costos de error: el núcleo inconsistente de la epistemología jurídica de Larry Laudan. Doxa. Cuadernos de Filosofía del Derecho, v. 43, 2020 , p. 402. 


\section{Funções dos standards de prova}

É possível verificar que os estândares probatórios possuem três principais funções: a) orientação dos sujeitos processuais; b) guia objetivo para a avaliação das provas (heurística) e c) distribuição dos riscos.

Em relação à função de orientação, o standard tem por um de seus objetivos a diminuição da natural incerteza encontrada nos julgamentos sobre os fatos - dentre eles os proferidos pelo Poder Judiciário -, ao servir como um guia de atuação dos diversos sujeitos processuais.

A sua definição interfere na atuação das partes, advogados e juízes. Em relação às partes, cabe a elas coletar diversos elementos probatórios, como os documentos, identificar testemunhas, sendo necessário que o estândar probatório seja levado em conta no momento de acionar o Poder Judiciário. Para os advogados, serve como uma orientação mediante a qual haverá um melhor assessoramento dos seus clientes, bem como para a tomada de decisões e a forma de apresentação dos seus argumentos para o juiz ou para o júri. Importante destacar que os estândares probatórios, do ponto de vista das partes e dos advogados, têm uma atuação até mesmo pré-processual, sendo utilizado, por exemplo, para definir se há elementos probatórios suficientes para ingressar em juízo.

Do ponto de vista dos julgadores, atua como um guia objetivo para a tomada das decisões fáticas ${ }^{25}$ (função heurística) ${ }^{26}$. Além disso, trata-se de um conceito que traz mais segurança à aplicação de diversos outros institutos do direito processual, tais como as presunções, a presunção de inocência, o ônus da prova, dentre outros.

A inexistência de estândares diminui a possibilidade de calculabilidade das possíveis decisões fáticas no processo. Deve se ter em mente que um pressuposto básico do direito é a redução da complexidade e da insegurança jurídica, sendo um desses elementos para diminuição da incerteza a fixação de um grau de corroboração necessário para que uma decisão seja proferida. ${ }^{27}$

${ }^{25}$ TWINING, William; SCHUM, David; ANDERSON, Terence. Analysis of evidence. $2^{\mathrm{a}}$ ed. Cambridge: Cambridge University Press, 2005, p. 225.

${ }^{26}$ GASCÓN ABELLÁN, Marina. Sobre la posibilidad de formular estándares de prueba objetivos. Doxa, Cuadernos de Filosofía del Derecho, n. 28, 2005, p. 129.

${ }^{27}$ CLERMONT, Kevin M. Standards of decision in law... cit., p. 3. De forma semelhante, destacando a segurança jurídica como uma "condição estrutural de qualquer ordenamento jurídico": ÁVILA, Humberto. 
A inexistência de um standard probatório expresso, seja por meio da atuação da jurisprudência ou da legislação, não significa que ele não exista. ${ }^{28}$ Como apontado, trata-se de elemento presente em qualquer decisão, o problema é que, na inexistência de uma prévia determinação pelo direito, essa tarefa acaba pertencendo ao juiz, que irá fixar, implicitamente, o seu próprio standard, a partir da sua ponderação de valores. De certa forma, a situação acaba sendo que a prova é suficiente na medida em que o julgador considere ser ela suficiente, ${ }^{29}$ impedindo, assim, um controle intersubjetivo adequado pelas partes. De qualquer forma, nessa hipótese, a função de orientação das partes e mesmo de uma adequada distribuição de riscos resta impedida, pela impossibilidade de conhecimento das razões e, mais especificamente, de qual standard teria sido utilizado.

Tem-se ainda a função justificatória, mediante a qual o standard probatório atua como um critério conforme o qual deve ser construída a justificação da decisão sobre os fatos. Em outros termos, a decisão não estaria adequadamente justificada se não estão presentes os elementos que compõem o standard aplicável ao caso concreto. ${ }^{30}$

Por fim, tem-se a distribuição dos riscos das decisões sobre os fatos. ${ }^{31}$ As decisões sobre os fatos no processo são tomadas em um ambiente de incerteza, sendo natural a existência de erros, tanto de falsos positivos (por exemplo, uma condenação errônea penal), quanto de falsos negativos (por exemplo, a absolvição de um criminoso).

Quanto maior a exigência probatória para um dado direito material, tem-se uma alteração esperada na distribuição dos erros, havendo um menor número de falsos positivos, mas, por outro lado, um maior número de falsos negativos. Por exemplo, uma maior exigência de suficiência probatória tende a aumentar o número de culpados materiais que serão absolvidos e diminuir o número de inocentes materiais que serão condenados.

Segurança jurídica: entre permanência, mudança e realização no direito tributário. São Paulo: Malheiros, 2011, p. 106-107.

${ }^{28}$ Destaca Danilo Knijnik que "Na experiência judiciária brasileira, não se tem o hábito de, previamente, indicar o modelo de constatação utilizado, embora necessariamente um modelo esteja implicado no decidir" (KNIJNIK, Danilo. A prova nos juízos cível, penal e tributário... cit., p. 32).

${ }^{29}$ Destacando os problemas dessa situação tautológica: VIALE DE GIL, Paula A.. ¿La prueba es suficiente cuando es suficiente? Aproximación a la construcción de la decision de suficiente de la prueba en materia penal... cit.

${ }^{30}$ GASCÓN ABELLÁN, Marina. Sobre la posibilidad de formular estándares de prueba objetivos... cit., p. 138.

${ }^{31} \mathrm{O}$ tema é aprofundado em: PEIXOTO, Ravi. Standards probatórios no direito processual brasileiro... cit., p. $129-154$ 
É perceptível uma forte conexão das funções do standard de prova com o princípio da segurança jurídica. A adequada orientação, seja da conduta dos sujeitos processuais, seja da justificação das provas, apenas é corretamente exercida se o standard probatório for objetivo e invariável em relação a um mesmo grupo de casos. Ora, as partes apenas podem planejar sua atuação processual caso tenham conhecimento prévio de uma suficiência probatória objetiva. Mesmo a questão da distribuição de riscos depende da utilização de standards probatórios objetivos e seguros, eis que, ausente qualquer precisão nas suficiências probatórias, é inviável qualquer projeção de alteração dos riscos de erros nas decisões sobre os fatos.

\section{Natureza jurídica do standard probatório}

O estândar probatório deve ser compreendido como uma questão de direito, tendo conexão direta com o momento de valoração da prova. ${ }^{32}$ De forma mais específica, pode-se afirmar que se trata de uma regra de decisão, na medida em que aponta o grau de corroboração necessário das provas para que se considere provada uma hipótese fática. ${ }^{33}$ Trata-se de conceito de caráter normativo, cabendo ao direito a definição dos standards de prova a serem aplicados nos diversos casos concretos, sendo desejável uma imposição normativa entre essas várias opções. ${ }^{34}$

Uma vez fixado o standard para um grupo de fatos, ele deve ser obrigatoriamente aplicado nos processos que envolvam tais fatos, não devendo variar de acordo com as circunstâncias do caso. ${ }^{35}$ Tanto o devido processo legal, compreendido em seu elemento de imparcialidade e de impedir restrições irracionais, ${ }^{36}$ como o princípio da

\footnotetext{
${ }^{32}$ KNIJNIK, Danilo. A prova nos juízos cível, penal e tributário... cit., p. 31; CARPES, Arthur Thompsen. A prova do nexo de causalidade na responsabilidade civil. São Paulo: RT, 2016, p. 135; SOBA BRACESCO, Ignacio M.. La predeterminación normativa de los estándares de prueba (um derivado de la seguridade jurídica). Revista Eletrônica de Direito Processual - REDP, v. 21, n. 2, mai./ago.-2020, disponível em: www.redp.uerj.br, acessado em 10 de maio de 2020, p. 205-206.

${ }^{33}$ TUZET, Giovanni. Assessment criteria or standards of proof? An effort in clarification... cit., p. 6.

${ }^{34}$ GUERRA, Marcelo Lima. Prova Judicial: uma Introdução. Fortaleza: Boulesis Editora. Edição do Kindle, 2016, p. 106.

${ }^{35}$ Em sentido contrário, defendendo que "O standard de prova precisa ser adequado ao caso concreto, fazendo parte daquilo que se pede ao Judiciário que, incidentalmente, decida". (TRENTO, Simone. Os standards e o ônus da prova: suas relações e causas da variação. Revista de Processo. São Paulo: RT, n. 226, dez.-2013, p. 167).

${ }^{36}$ LAUDAN, Larry. Verdad, error y proceso penal... cit., p. 104.
} 
segurança jurídica exigem que um mesmo standard seja aplicado a um mesmo grupo de fatos e que seja de prévio conhecimento das partes. ${ }^{37}$ A possibilidade de readequação do standard a partir das dificuldades concretas viola diretamente o princípio da segurança jurídica, especialmente em seu aspecto subjetivo, qual seja, a confiança legítima, ao surpreender a parte que atua em conformidade com um standard probatório que era esperado e tem a suficiência alterada de forma casuística.

Além disso, não se pode ignorar que permitir a alteração circunstancial do estândar probatório é também conceder um papel de protagonismo inadequado ao julgador, que acabará tendo o poder de definir o resultado do processo. ${ }^{38}$ Afinal, o standard é que definirá a confiabilidade exigida das provas e, sendo alterado, o resultado da decisão probatória será diretamente modificado.

\section{O momento da decisão sobre os standards a serem exigidos no processo}

A situação ideal é a que os standards sejam fixados anteriormente ao início do processo, por gerar maior segurança jurídica para todos os sujeitos processuais, em especial para as partes. Trata-se de uma possibilidade que tende a ocorrer nas situações em que a legislação já os preveja ou exista algum posicionamento jurisprudencial consolidado, que gere considerável segurança jurídica aos participantes do processo de que uma determinada suficiência probatória se aplica a um determinado grupo de casos.

No entanto, em não sendo possível identificar previamente, com segurança, os standards de prova a ser aplicados a cada decisão, é necessária a devida reflexão acerca do momento processual em que devem ser indicados pelo juiz.

Como no Brasil ainda não há uma adequada definição legislativa sobre os standards de prova, em especial em relação àqueles aplicáveis às decisões definitivas de mérito, enquanto ainda não tiver ocorrido a consolidação judicial, o juiz deve sempre indicar, antes da decisão definitiva, qual a suficiência probatória necessária para que as partes possam ter um parâmetro para a sua atividade probatória. No processo civil, o momento

${ }^{37}$ SOBA BRACESCO, Ignacio M.. La predeterminación normativa de los estándares de prueba (um derivado de la seguridade jurídica)... cit., p. 191.

${ }^{38}$ Com preocupação semelhante: KNIJNIK, Danilo. A prova nos juízos cível, penal e tributário... cit., p. 33. 
adequado para tanto é na decisão de saneamento e organização do processo, pois é nesse momento que deve ocorrer a delimitação das "questões de fato sobre as quais recairá a atividade probatória, especificando os meios de prova admitidos" (art. 357, II, CPC), bem como a definição da distribuição do ônus da prova, o que deve abranger também a questão da suficiência da prova.

No processo penal, por não haver um momento específico para a organização do processo, seria adequado que o juiz indicasse qual será o standard da decisão final antes do início da fase da dilação probatória. Portanto, essa indicação da suficiência probatória pode ocorrer na decisão de recebimento da denúncia (art. 396, CPP), devendo ser proferida até o momento de designação da audiência (art. 399, CPP).

\section{A quem cabe definir os standards em cada ordenamento jurídico}

Foi possível identificar, até o momento, que os estândares probatórios cumprem a função de orientação dos sujeitos processuais, de justificação da decisão, distribuição de riscos e, ainda, que é em um conceito normativo. Tendo em vista tais características, é correto afirmar que, preferencialmente, cabe ao próprio legislador a fixação dos standards probatórios de cada ordenamento jurídico ${ }^{39}$, uma vez que pertence ao Poder Legislativo a incumbência primordial de traduzir a adequada distribuição dos riscos de erros de cada país na legislação, do qual faz parte a fixação dos estândares probatórios. É preferível que seja o Poder Legislativo o responsável por decidir qual a preferência dos riscos a serem assumidos: é preferível a falsa condenação de um inocente ou a falsa absolvição de um culpado; mais ainda, qual a relação entre esses dois tipos de riscos para que o standard seja mais ou menos exigente.

Esse raciocínio é ainda mais relevante no contexto dos países do civil law, em que há prevalência do direito legislado. Não por acaso, nos países que se utilizam dos estândares, no direito penal, tais como Chile, Colômbia e Itália, coube ao legislador a escolha do standard aplicável. Essa situação, por outro lado, não é verificada nos países do common

\footnotetext{
${ }^{39}$ Destacando competir ao legislador a fixação dos estândares: REYES MOLINA, Sebastián. Presunción de inocencia y estándar de prueba en el proceso penal: reflexiones sobre el caso chileno. Revista de Derecho, v. XXV, n. 2, dez.-2012, p. 231.
} 
law, onde geralmente a tarefa de fixação dos standards pertence ao próprio Poder Judiciário, possibilidade que não é desejável para os países do civil law. Para além da questão da legitimidade, há a dificuldade relativa à segurança jurídica, face à difícil relação com a obrigatoriedade dos precedentes.

Em sendo o risco de erros inerente à falibilidade humana na tomada de decisões e o limitado conhecimento acerca do que ocorre na realidade dos fatos, tem-se um efetivo dilema a ser analisado por cada ordenamento jurídico. ${ }^{40}$

Isso não significa, no entanto, que a ausência da atuação do Poder Legislativo deixa o ordenamento jurídico livre de qualquer espécie de standard. Consoante afirmando no início deste texto, o estândar probatório é um requisito necessário do procedimento probatório: sem ele, não há um critério adequado para a tomada de decisão sobre a condição de provada, ou não, de uma determinada hipótese.

Em países nos quais apenas um dos elementos decisórios é mais explícito, qual seja, o critério de avaliação da prova, essa omissão normativa implica incorporação do modelo de avaliação no estândar probatório ou mesmo no desenvolvimento de critérios de suficiência probatória pela jurisprudência e doutrina. Tanto a doutrina quanto as decisões judiciais devem debater a temática e, com o tempo, uma posição dominante acaba por prevalecer. $^{41}$

A primeira hipótese pode ser observada nos EUA, em que há utilização do standard acima de qualquer dúvida razoável, no qual a avaliação da prova acaba tendo por base a exigência de uma avaliação das provas baseada na razoabilidade. ${ }^{42}$ Ou seja, em tal situação, a existência de um dos dois elementos da decisão da prova condiciona o faltante. ${ }^{43}$

$\mathrm{Na}$ segunda hipótese, em que há o desenvolvimento de um standard, é imprescindível a atuação dos precedentes judiciais como uma forma de conceder estabilidade ao eventual standard que vier a prevalecer no determinado ordenamento jurídico. Como apontado neste texto, o standard não pode funcionar de maneira aleatória,

\footnotetext{
40 ZUCKERMAN, Adrian; ROBERTS, Paul. Criminal evidence. Oxford: Oxford University Press, 2004, p. 355.

${ }^{41}$ TUZET, Giovanni. Assessment criteria or standards of proof? An effort in clarification... cit., p. 16.

${ }^{42}$ PICINALI, Federico. The threshold lies in the method: Instructing jurors about reasoning beyond reasonable doubt. The International Journal of Evidence \& Proof, v. 19, n. 3, 2015.

${ }^{43}$ TUZET, Giovanni. Assessment criteria or standards of proof? An effort in clarification... cit., p. 15.
} 
pertencendo a cada julgador; dessa forma, não traz qualquer parâmetro decisório seguro, apenas perpetuando uma subjetividade de difícil controle.

Nesse ponto, afigura-se imprescindível a conexão entre os estândares probatórios e a teoria dos precedentes valorizada pelo CPC, em especial os artigos 926 e 927. Uma vez que os estândares probatórios são definidos como questões de direito, incumbe aos tribunais superiores a fixação e a uniformização dos estândares aplicáveis ao direito brasileiro. Em havendo uma definição, esta deve ser respeitada e utilizada tanto pelos próprios tribunais, quanto pelos órgãos jurisdicionais a eles vinculados.

\section{A epistemologia e a sua função na fixação dos estândares probatórios}

A discussão sobre a forma de enunciação dos estândares probatórios é naturalmente inserida em um contexto maior, qual seja, o da forma mais adequada de visualizar o próprio funcionamento do direito probatório. Este texto tem como premissa a tese de que é possível - e desejável - um direito probatório no qual a constatação de que uma determinada hipótese, para ser tida como provada, dependa da análise racional das provas disponíveis. ${ }^{44} \mathrm{O}$ convencimento do julgador deve ser baseado nas provas; a constatação de que uma hipótese fática está provada foca nos elementos probatórios e não na persuasão do julgador. Em suma, trata-se de um ponto de vista objetivo do julgamento das provas no campo do direito.

Seguindo essa lógica, os standards de prova não podem seguir um caminho diverso. Os estândares de prova, na medida do possível, não podem ter por base a utilização de critérios subjetivos, sob pena de serem incapazes de servir à função que lhes incumbe, qual seja, a de servir como um parâmetro de suficiência probatória e de orientação da justificação decisória para os julgadores e, fosse tal modelo subjetivo, não traria qualquer incremento ao controle das decisões, igualando-se à simples ausência de qualquer parâmetro.

Perde-se, com uma conceituação subjetiva, a função de orientação do standard, eis que a decisão de suficiência da prova acaba dependendo das concepções pessoais do

\footnotetext{
${ }^{44} \mathrm{O}$ tema foi desenvolvido em: PEIXOTO, Ravi. Standards probatórios no direito processual brasileiro... cit., p. 33-59.
} 
julgador, impedindo um adequado controle intersubjetivo ${ }^{45}$ e diminuindo a calculabilidade das decisões, tendo em vista não ser possível antecipar minimamente as provas necessárias para que se obtenha uma decisão favorável para a parte. ${ }^{46}$

O estândar probatório deve ser um elemento que auxilie no controle intersubjetivo das decisões sobre os fatos, não se podendo admitir que essa esfera decisional funcione como uma espécie de caixa-preta inacessível da decisão. Como ressalta Danilo Knijnik, é com a identificação do standard que passa a ser possível o controle de sua utilização, impedindo que o jurisdicionado fique sujeito à subjetividade do juiz, que teria o poder de definir o modelo de constatação aplicável, bem como o seu conteúdo de forma implícita. ${ }^{47}$

Nesse ponto, vem em auxílio a epistemologia, especialmente a epistemologia jurídica, que tem por objetivo o estudo das questões relativas às provas, mais especificamente como ela deve ser estruturada e indicar as melhores formas de se identificar a força e a relevância dos elementos probatórios. ${ }^{48}$

A ligação entre a epistemologia e os estândares probatórios está na sua aptidão de fornecer suporte para o desenvolvimento de um estândar objetivo. Não incumbe a ela decidir qual standard deve ser adotado, mas, tendo por base as características de cada um deles, auxiliar na forma de traduzir tais particularidades em modelos objetivos de constatação probatória e guiar a atuação dos julgadores. ${ }^{49}$ Portanto, o seu objetivo é o de auxiliar a construção de um modelo racional na fixação dos standards probatórios, evitando o recurso a estados subjetivos.

A subjetividade pode ser entendida de duas formas diferentes. A primeira delas refere-se à utilização de conceitos que remetem a uma confiança subjetiva ou a um estado

\footnotetext{
45 VIALE DE GIL, Paula A.. ¿La prueba es suficiente cuando es suficiente? Aproximación a la construcción de la decision de suficiente de la prueba en materia penal... cit. p. 144.

${ }^{46}$ FERRER BELTRÁN, Jordi. La prueba es libertad, pero no tanto: una teoria de la prueba cuasibenthamiana... cit., p. 35; AGUILERA GARCÍA, Edgar R.. Jordi Ferrer y la tradición racionalista de la prueba jurídica: una mirada crítica. Isonomía. Revista de Teoría y Filosofia del Derecho, n. 44, abr.-2016, p. 175.

${ }^{47}$ KNIJNIK, Danilo. A prova nos juízos cível, penal e tributário... cit., p. 33.

${ }^{48}$ HAACK, Susan. Evidence matters: Science, proof and truth in the law. Cambridge: Cambridge University Press, 2014, p. 6.

${ }^{49}$ Nesse sentido: PARDO, Michael. Estándares de prueba y teoria de la prueba. In: VÁZQUEZ, Carmen (coord). Estandáres de prueba y prueba científica - ensayos de epistemología jurídica. Madri: Marcial Pons, 2013, p. 103.
} 
mental discricionário do julgador. ${ }^{50}$ Por outro lado, a subjetividade também pode ocorrer por conta da utilização de conceitos, que, embora não remetam a um estado subjetivo, sejam excessivamente vagos ou imprecisos. Ou seja, embora não haja uma expressa remissão ao subjetivismo, isso acaba ocorrendo porque, como incumbe ao juiz o preenchimento do standard, conceitos extremamente vagos não permitem um controle adequado da decisão. ${ }^{51}$

Significa, então, que os standards de prova devem ser formulados a partir das conexões lógicas que devem existir entre as provas disponíveis e as hipóteses fáticas concorrentes para que se possa considerá-las como provadas, mediante a utilização de conceitos objetivos, impedindo a remissão a algum estado mental discricionário do juiz. É nesse sentido que a epistemologia tem o papel de auxiliar na objetivação do estândar probatório: fornecendo fundamentos teóricos para a conceituação dos estândares. Por outro lado, é evidente que cada ordenamento jurídico deverá, tendo por base o direito material, dispor sobre os estândares a serem aplicados às situações concretas. No entanto, existem pontos de conexão entre esses dois pontos de vista.

Isso ocorre porque, por mais que não caiba à epistemologia fixar abstratamente os estândares, ela possui o papel tanto de: i) sugerir estândares tendo em vista a avaliação das questões políticas e culturas de um determinado país a ser adotado, seja pelo Poder Legislativo, seja pelo Poder Judiciário; ii) indicar uma interpretação objetiva de standards já fixados pelo Poder Legislativo ou Judiciário e, ainda, iii) criticar o estândar adotado por ele não ter justificativa racional em relação aos riscos de erros ao qual se propõe, ou mesmo que as estimativas sociais a respeito dos custos dos erros em questão não foram realizadas com base em metodologias adequadas. ${ }^{52}$ Pode-se utilizar como exemplo um país no qual haja a fixação de um standard particularmente elevado para questões patrimoniais e outro mais baixo para crimes como o homicídio e que essa análise das estimativas sociais esteja em completo desacordo com a realidade no qual inserido.

As duas perspectivas são necessárias e complementares entre si. A epistemologia não deve fixar standards ignorando o contexto no qual inserido um determinado país,

\footnotetext{
${ }^{50}$ LAUDAN, Larry. Por qué un estándar de prueba subjetivo y ambiguo no es un estándar. Doxa, Cuadernos de Filosofía del Derecho, n. 28, 2005, p. 105.

51 GONZÁLEZ LAGIER, Daniel. ¿Es posible formular un estándar de prueba preciso y objetivo? Algunas dudas desde un enfoque argumentativo de la prueba... cit., p. 13.

${ }^{52}$ Especificamente sobre esse último ponto, cf.: AGUILERA GARCÍA, Edgar R.. Jordi Ferrer y la tradición racionalista de la prueba jurídica: uma mirada crítica... cit., p. 181.
} 
preocupando-se apenas com um ideal de decisões que proporcionem uma melhor análise acerca dos fatos, pois esse não é o papel primordial dos standards, que também estão diretamente relacionados com a distribuição dos riscos de erros. Por outro lado, o Poder Judiciário e o Legislativo não devem estabelecer standards eminentemente subjetivos, que impeçam qualquer controle intersubjetivo ou que ignorem os valores envolvidos nos fatos tipificados pelo direito. Assim, é possível concluir que a epistemologia possui um papel de filtrar os elementos políticos e culturais para que esses se aproximem de um modelo de valoração objetiva das provas e das estimativas sociais naquele momento e local nos quais estabelecido o standard.

\subsection{Os estândares probatórios auxiliam no processo decisório e podem ser fixados de forma objetiva? Uma análise crítica da doutrina.}

De acordo com Daniel González, um standard de prova ideal deveria ser capaz de indicar uma suficiência probatória sem remeter a estados mentais, ser preciso, objetivo e enfrentar o problema de que o grau de confirmação é um conceito gradual. ${ }^{53}$ De acordo com o autor, embora seja possível a construção de um standard probatório com viés mais objetivo, que não dependa apenas do estado mental do juiz, não seria possível a fixação de um conceito tão preciso a ponto de frear a discricionariedade judicial.

Para tanto, afirma que a fixação dos estândares probatórios apenas faz sentido em um sistema de livre convencimento motivado, no qual houve uma delegação inicial ao juiz para valorar a prova e decidir quando a prova é suficiente para uma determinada hipótese estar provada. O standard teria por objetivo diminuir a discricionariedade existente no momento de constatação da suficiência de prova, no entanto, a obtenção do modelo ideal (sem qualquer discricionariedade) acabaria por gerar uma volta inadequada a um sistema assemelhado ao sistema das provas legais, mediante a predeterminação do valor das provas. Portanto, ele acaba concluindo que um standard adequadamente preciso acabaria voltando

${ }^{53}$ GONZÁLEZ LAGIER, Daniel. ¿Es posible formular un estándar de prueba preciso y objetivo? Algunas dudas desde un enfoque argumentativo de la prueba... cit., p. 13 
ao problema existente no sistema da prova legal, gerando excessiva rigidez na atuação judicial. ${ }^{54}$

O problema que pode ser encontrado na reflexão de Daniel González é que, para ele, a função do standard apenas seria alcançada caso fosse possível desenvolver conceitos extremamente precisos a ponto de retirar a discricionariedade judicial. Ocorre que um modelo de constatação probatória objetivo não precisa chegar ao ponto de voltar a um sistema de prova legal para que seja útil. Como destaca Danilo Knijnik, "o fato de não se poder quantificar esses graus em balança de farmacêutico (...) não leva tudo para o arbítrio". ${ }^{55}$ Uma definição precisa, que impeça qualquer mínimo de discricionariedade decisória é impossível; no entanto, uma delimitação mínima tem por função permitir um maior controle intersubjetivo mediante critérios racionais da decisão sobre os fatos.

Para este texto, situação caótica é a existente no direito brasileiro atual, no qual os standards probatórios simplesmente não existem, ou, se existem, atuam em uma esfera completamente subjetiva e incontrolável do julgador dos fatos. Dessa forma, não há sequer um guia para o grau de suficiência probatória.

O objetivo do estândar probatório não é - até por uma incapacidade de fazê-lo o de conter toda a discricionariedade judicial, mas servir como um guia para melhorar o controle intersubjetivo das decisões fáticas. A inexistência de um standard probatório qualquer, ou um que remeta a estados mentais do julgador, torna a decisão fática praticamente inacessível à impugnação. Afinal, se o estândar probatório é fixado pelo juiz ou formulado com a remessa a estados mentais discricionários do julgador, a impugnação tende ao fracasso.

Uma outra reflexão acerca da conceituação dos standards probatórios vem de Juan Carlos Bayon. Segundo o autor, seriam quatro os requisitos para a fixação de um standard probatório: i) não pode ser subjetivo, remetendo a estados mentais do julgador; ii) deve ser formulado de maneira a permitir o seu controle por meio de um procedimento intersubjetivamente controlável; iii) sua formulação deve ser capaz de gerar a distribuição

54 GONZÁLEZ LAGIER, Daniel. ¿Es posible formular un estándar de prueba preciso y objetivo? Algunas dudas desde un enfoque argumentativo de la prueba... cit., p. 19-20.

${ }^{55}$ KNIJNIK, Danilo. A prova nos juízos cível, penal e tributário... cit., p. 36. Susan Haack chega a duvidar se seria adequada uma definição extremamente precisa dos standards, mesmo que ela fosse possível (HAACK, Susan. Evidence matters: science, proof and truth in the law... cit., p. 51). 
de risco que se afirme justificada; e iv) essa distribuição dos riscos deve decorrer da qualidade dos elementos probatórios e não de outros fundamentos. ${ }^{56}$

De forma bastante resumida, a conclusão de Juan Carlos Bayon é que não existem mecanismos para que se verifique que o standard é capaz de gerar a distribuição de riscos que se afirme justificada. Os critérios atualmente existentes permitem exclusivamente uma comparação de forma a verificar qual das hipóteses é melhor, mas seria incapaz de distribuir os erros nos moldes do que seria desejado pelo standard. ${ }^{57}$ A melhor forma, então, de distribuir os riscos seria por meio da formulação de regras de admissibilidade probatórias, ônus da prova, valores das provas, capazes de incorporar os critérios de distribuição dos riscos desejados. ${ }^{58}$

A reflexão de Bayon é importante, no entanto, ela parece se dirigir a um standard que atua em um plano ideal, com uma atuação completamente objetiva, impedindo qualquer elemento de subjetividade e capaz de obter o percentual ideal de erros esperados. ${ }^{59} \mathrm{O}$ objetivo dos standards é mais modesto, qual seja, o de trazer mais um elemento de controle e de aproximar as decisões à assunção de riscos esperadas por aquela sociedade em questão. Ademais, Bayon não chega sequer a elencar exemplos nos quais a função do standard probatório poderia ser substituída, sendo, até o momento, a melhor solução para os seus propósitos.

De acordo com Jordi Nieva, os standards probatórios estariam dentro do contexto da livre valoração da prova e, no sistema norte-americano do júri, teria a função de orientar os jurados acerca dos requisitos relativos à suficiência probatória. Ocorre que, segundo o autor, embora os standards tenham por objetivo a função de orientar a livre valoração da prova, não possuem muita utilidade para as decisões nos casos concretos, eis que não possuem aptidão para explicar as razões pelas quais um juiz resolveu um caso de um modo ou de outro. Em não tendo aptidão de controlar os critérios de valoração, os

\footnotetext{
56 BAYON, Juan Carlos. Epistemología, moral y prueba de los hechos: hacia un enfoque no benthamiano. Revista Jurídica Mario Alario D'Filippo, v. 2, n. 4, 2010, disponível em: https://revistas.unicartagena.edu.co, acessado em 25 de julho de 2019, p. 19.

${ }^{57}$ BAYON, Juan Carlos. Epistemología, moral y prueba de los hechos: hacia un enfoque no benthamiano... cit., p. 22-24.

${ }^{58}$ BAYON, Juan Carlos. Epistemología, moral y prueba de los hechos: hacia un enfoque no benthamiano... cit., p. 26.

${ }^{59}$ Com raciocínio semelhante: ARAYA NOVOA, Marcela Paz. El controle ex post de la calidad de los enunciados probatorios en materia penal em Chile. De la epistemología a la práxis... cit., p. 335.
} 
standards, mesmo com uma pretensão de objetividade, poderiam ser equiparados aos requisitos do bom senso ou da íntima convicção. ${ }^{60}$

Inicialmente, Nieva parece tentar acoplar os standards probatórios com a própria valoração da prova, o que é uma visão incorreta do tema. Embora sejam conceitos com uma necessária imbricação, eles não podem ser confundidos, pois, como a valoração almeja identificar o peso de cada prova/do conjunto probatório, o standard serve como guia para identificar o peso necessário para que uma hipótese fática esteja comprovada. De fato, os standards não têm - e nunca tiveram - pretensão de permitir um controle da valoração específica dos elementos probatórios, mas da conclusão desse raciocínio.

Sua função é a de servir de guia para a valoração da prova - que tem por base a persuasão racional -, atuando como uma regra de decisão, permitindo que o julgador verifique se, dentre as hipóteses fáticas disponíveis, alguma delas alcance o grau de suficiência probatória exigido para aquele direito material. Em outros termos, o standard probatório não indica os critérios para que cada uma das provas seja valorada, mas um critério mediante o qual se considera provada uma hipótese, caso seja atingida uma suficiência mínima.

Ao contrário da suposta inutilidade dos estândares defendida por Nieva, em pesquisas empíricas com júris simulados, houve a identificação tanto de que a alteração do standard modifica o resultado dos julgamentos quanto a importância da comparação entre os diversos estândares para a realização do julgamento das questões fáticas. Enfim, ao que consta, os estândares possuem considerável utilidade no sentido de orientar o julgamento dos fatos de acordo com um modelo de constatação exigido pelo direito, o que é basicamente a sua função.

\subsection{Os standards probatórios e a alteração dos julgamentos: a sua atuação na dinâmica dos julgamentos dos fatos}

\footnotetext{
${ }^{60}$ NIEVA FENOLL, Jordi. La valoración de la prueba... cit., p. 85-88. O autor volta a abordar o tema de forma semelhante em texto mais recente: NIEVA FENOLL, Jordi. Carga de la prueba y estándares de prueba: dos reminiscencias del pasado. InDret, n. 3, 2020, disponível em: https://indret.com/carga-de-la-prueba-yestandares-de-prueba-dos-reminiscencias-del-pasado/, acessado em 18 de agosto de 2020.
} 
Como visto, parte das críticas feitas aos estândares probatórios tem por base a afirmação de sua incapacidade de guiar as decisões, o que acabaria por demonstrar a sua inutilidade. Ocorre que, ao contrário do que afirmam tais autores, há indicativos, por meio de pesquisas empíricas, de que a inserção de diferentes standards probatórios possui a aptidão de alterar as decisões sobre os fatos.

Em pesquisa realizada em júris simulados por Norbert Kerr e outros, foi identificado que, com a simples variação na forma de enunciação do estândar que exige prova acima de toda dúvida razoável para a prolação de sentença penal condenatória, houve uma alteração de $26 \%$ na taxa de condenação do acusado, tendo por base um caso criminal complexo. ${ }^{61}$ Em outra pesquisa organizada por Irwin Horowitz e Laird Kirkpatrick, também foi possível observar que a alteração na definição do conceito de prova acima de dúvida razoável modifica a taxa de condenações e a preocupação do júri em relação à exigência probatória do caso, aumentando as discussões sobre os elementos probatórios disponíveis. ${ }^{62}$ Em ambas as pesquisas, as diferentes formas de expressão do estândar acima de toda dúvida razoável utilizaram expressões linguísticas, evitando o uso de porcentagens.

Por outro lado, em outra pesquisa empírica, foram testadas duas formas de expressão dos standards probatórios (preponderância da prova, prova clara e convincente e prova além de toda dúvida razoável): uma quantificada em porcentagens e outra baseada na mudança da expressão linguística. Na utilização dos estândares baseados em números, houve maior variação nos resultados, diminuindo a quantidade de decisões desfavoráveis ao autor do processo na medida em que aumentada a exigência probatória, o que não ocorreu com a variação da alteração apenas na forma de enunciação do estândar nas instruções dadas ao júri simulado. ${ }^{63}$ Por outro lado, a utilização dos diferentes standards expressos de forma verbal tiveram considerável efetividade na alteração dos julgamentos quando enunciados de

\footnotetext{
${ }^{61}$ KERR, Norbert; ATKIN, Robert S.; STASSER, Garold; MEEK, David; HOLT, Robert W.; DAVIS, James H. Guilt beyond reasonable doubt: effects of concept definition and assigned decision rule on the judgments of mock jurors. Journal of Personality and Social Psychology, v. 34, n. 2, 1976, p. 291.

${ }^{62}$ HOROWITZ, Irwin. A.; KIRKPATRICK, Laird. C. A concept in search of a definition: the effects of reasonable doubt instructions on certainty of guilt standards and jury verdicts. Law and Human Behavior, v. 20, n. 6, dez.-1996, p. 667-668.

${ }^{63}$ KAGEHIRO, Dorothy K.; STANTON, W. Clark. Legal vs. quantified definitions of standards of proof. Law and Human Behavior, v. 9, n. 2, 1985, p. 169.
} 
forma comparativa, caso em que era indicado ao júri que existiriam três standards diferentes e que, na situação concreta, seria aplicado um determinado modelo de constatação. ${ }^{64}$

Em outra pesquisa, houve um resultado um pouco diverso, eis que foi identificado que, apresentados os mesmos elementos probatórios, a decisão acerca da eventual condenação de um réu é alterada a partir do standard utilizado, mesmo com expressões linguísticas, se a eles é indicado apenas a preponderância da evidência ou é exigido o standard de prova acima de qualquer dúvida razoável. ${ }^{65}$

Michael D. Cicchini realizou duas pesquisas simuladas com júri. A primeira, em coautoria com Lawrence T. White, não alcançou resultados com diferenças significativas, quando os jurados foram apresentados ao mesmo caso, apenas com a diferença entre a nomenclatura dos três standards de forma isolada. Não houve, nessa pesquisa, uma apresentação comparativa entre os standards. Ou seja, a conclusão foi que a alteração dos standards não alteraria significativamente o resultado dos julgamentos. ${ }^{66}$

No entanto, em outra pesquisa, foi levantada a seguinte questão: é possível que os standards de prova funcionem melhor de forma comparada, ou seja, a apresentação do standard de prova acima de qualquer dúvida razoável, apresentado de forma isolada, atue diversa do que se ele for apresentado de forma comparativa aos outros dois standards. ${ }^{67} \mathrm{~A}$ conclusão da pesquisa foi considerada significativa, eis que o grupo em que apresentado o standard de forma isolada gerou uma taxa de absolvição de 32,6\% e, de forma comparada, a taxa foi de $42,4 \%$. Além disso, foi possível perceber que, requerendo aos jurados que apresentem a confiança subjetiva necessária para a condenação nas duas hipóteses, houve uma considerável diferença, pois, para o primeiro grupo, a prevalência ocorreu entre 60 e $65 \%$ e, no segundo grupo, entre 70 e $75 \%{ }^{68}$

Naturalmente, embora os júris simulados não sejam uma representação real dos júris, pois, em geral, há uma abreviação do caso, com diminuição do tempo disponível para

\footnotetext{
${ }^{64}$ KAGEHIRO, Dorothy K.; STANTON, W. Clark. Legal vs. quantified definitions of standards of proof... cit., p. 173.

${ }^{65}$ ENGEL, Christoph. Preponderance of evidence versus intime conviction: a behavioral perspective on a conflict between american and continental european law. Vermont Law Review, v. 33, 2009, p. 460-465.

${ }^{66}$ CICCHINI, Michael; WHITE, Lawrence T. Is reasonable doubt self-defining? Villanova Law Review, v. 64, n. 1, 2019, p. 13.

${ }^{67}$ CICCHINI, Michael D. Reasonable doubt and relativity. Washington and Lee Law Review, v. 76, n. 4, 2019, p. 1467-1468.

${ }^{68}$ Idem, ibidem, p. 1472-1475.
} 
deliberação e, especialmente, a inexistência de consequências concretas do julgamento, ${ }^{69}$ os resultados dessas pesquisas podem ser utilizados para verificar, ao menos, uma tendência de que a alteração dos estândares também muda o resultado dos julgamentos no mundo real. ${ }^{70}$ Essa alteração ocorre especialmente quando os standards são apresentados de forma comparativa, ou seja, a percepção de que há mais de uma suficiência probatória no direito permite ao julgador dos fatos sopesar de forma mais adequada a exigência probatória para o caso específico no qual está atuando.

Uma última questão a ser considerada consiste no objeto de pesquisa: o júri. No Brasil, a atuação do júri é consideravelmente limitada, especialmente em comparação com os EUA, limitando-se aos crimes dolosos contra a vida (art. 5', XXXVIII, $d$, CFRB), portanto, a grande maioria dos julgamentos de fato será feita por julgadores profissionais e não por julgadores leigos.

Embora sejam raras as pesquisas empíricas comparando o julgamento entre o juiz e o júri, em pesquisa realizada em 1950, juízes que atuavam no júri foram questionados acerca de casos já julgados pelo júri e o resultado foi o de que havia coincidência do veredito em $78 \%$ dos $\operatorname{casos}^{71}$. Não se pode ignorar, no entanto, o fato de que em tais pesquisas, resta ausente um elemento crucial que está na atividade judicante, que consiste na exigência de justificação das decisões, que eventualmente poderia alterar os resultados.

Uma outra questão que pode ser levada em consideração e que pode tornar o standard mais efetivo no contexto da atuação do juiz profissional é a de que, em pesquisas, a taxa de confiança subjetiva necessária para a condenação é diversa para o jurado e para juízes profissionais. Para os juízes, em geral, a confiança subjetiva tida como apta a satisfazer o standard de prova acima de qualquer dúvida razoável é de $90 \%,{ }^{72}$ no entanto, em pesquisas com jurados, a porcentagem foi representada de forma muito diferente, geralmente atuando por volta de 60 a $65 \% .^{73}$

\footnotetext{
${ }^{69}$ HOROWITZ, Irwin. A.; KIRKPATRICK, Laird. C. A concept in search of a definition: the effects of reasonable doubt instructions on certainly of guilt standards and jury verdicts... cit., p. 291.

${ }^{70}$ No mesmo sentido: LIMA, Matheus Carneiro. Standards de prova no direito brasileiro. Dissertação de mestrado. São Paulo: USP, 2018, p. 76-78.

${ }^{71}$ Com menção à pesquisa, bem como uma análise das diferenças e semelhanças entre o julgamento pelo júri e pelo juiz profissional: SAKS, Michael J.; SPELLMAN, barbara A. The psychological foundations of evidence law. Nova Iorque: New York University Press, 2016, p. 33-56.

${ }^{72}$ SOLAN, Lawrence. Refocusing the burden of proof in criminal cases: some doubt about reasonable doubt. Texas Law Review, v. 78, 1999, p. 126.

${ }^{73}$ CICCHINI, Michael D. Reasonable doubt and relativity... cit., p. 1461-1462.
} 
De toda forma, parece possível inferir que, se o júri é afetado pela alteração do standard a ser exigido, conclusão semelhante pode ser levada à atividade do juiz. Mais ainda: como o juiz profissional lida com conceitos legais com uma maior familiaridade, e, no geral, possui uma forma diversa de encarar a confiança subjetiva pelos standards, é provável que ele consiga lidar melhor com os diferentes standards probatórios e suas respectivas aplicações. Como aponta Jordi Ferrer, como os juízes profissionais são uma espécie de repeat players, a eles é possível a devida capacitação para lidar adequadamente com a devida justificação das decisões de fato. ${ }^{74}$

Essa conclusão é auxiliada por pesquisas empíricas que indicam que as principais dificuldades do júri são a compreensão das instruções dos juízes, a aplicação do direito material e o conhecimento de conceitos legais, ${ }^{75}$ sendo inegável que o standard probatório, bem como suas formulações, são realizadas por meio de termos jurídicos e epistemológicos.

\section{Conclusão}

Esse artigo teve por objetivo apenas introduzir as principais características do tema dos estândares probatórios, sem qualquer pretensão de análise de quais estão sendo utilizados em outros países e mesmo de sugerir alguns específicos para o direito brasileiro. ${ }^{76}$

A proposta é singela: introduzir o tema e provocar a reflexão sobre as possíveis consequências de sua inserção na prática da valoração da prova no direito processual brasileiro. Foi possível verificar que se trata de uma questão de direito que tem três principais funções: a) orientação dos sujeitos processuais; b) guia objetivo para a avaliação das provas (heurística) e c) distribuição dos riscos.

As duas primeiras funções se relacionam com a objetivação das decisões sobre a prova, afinal, depois de valoradas as provas, é importante que haja um critério orientador para que se possa identificar quando alguma das hipóteses fáticas pode ser tida como provada.

\footnotetext{
74 FERRER BELTRÁN, Jordi. Sobre el deber de motivación de las decisiones probatorias y el juicio por jurados. La sentencia V.R.P., V.P.C. y otros vs. Nicaragua de la corte IDH... cit., p. 380.

75 ESSEX, Ryan; GOODMAN-DELAHUNTY, Jane. Judicial directions and the criminal standard of proof: improving juror comprehension. Journal of Judicial Administration, v. 24, n. 2, dez.-2014, p. 76.

76 Para análise dessas perspectivas, cf.: PEIXOTO, Ravi. Standards probatórios no direito processual brasileiro... cit., p. 157-320.
} 
Portanto, parece-nos extremamente importante que o tema dos standards probatórios seja devidamente introduzido no contexto da decisão probatória no direito processual brasileiro como mais um elemento para permitir um melhor controle intersubjetivo das decisões sobre os fatos.

\section{REFERÊNCIAS}

ABBOUD, Georges. Discricionariedade administrativa e judicial. São Paulo: RT, 2014.

ABEL LLUCH, Xavier. La valoración de la prueba en el proceso civil. Madri: La Ley, 2014.

AGUILERA GARCÍA, Edgar R.. Jordi Ferrer y la tradición racionalista de la prueba jurídica: una mirada crítica. Isonomía. Revista de Teoría y Filosofia del Derecho, n. 44, abr.-2016.

ARAYA NOVOA, Marcela Paz. El controle ex post de la calidad de los enunciados probatorios en materia penal en Chile. De la epistemología a la praxis. Tese de Doutorado. Girona: Universidade de Girona, 2016.

ÁVILA, Humberto. Segurança jurídica: entre permanência, mudança e realização no direito tributário. São Paulo: Malheiros, 2011.

BAYON, Juan Carlos. Epistemología, moral y prueba de los hechos: hacia un enfoque no benthamiano. Revista Jurídica Mario Alario D’Filippo, v. 2, n. 4, 2010, disponível em: https://revistas.unicartagena.edu.co, acessado em 25 de julho de 2019.

ACCATINO, Daniela. Certezas, dudas e propuestas en torno al estándar de la prueba penal. Revista de Derecho de la Pontifícia Universidad Católica de Valparaíso, v. XXXVII, jul./dez.-2011.

CARPES, Arthur Thompsen. A prova do nexo de causalidade na responsabilidade civil. São Paulo: RT, 2016.

CICCHINI, Michael D. Reasonable doubt and relativity. Washington and Lee Law Review, v. 76, n. 4, 2019.

CICCHINI, Michael; WHITE, Lawrence T. Is reasonable doubt self-defining? Villanova Law Review, v. 64, n. 1, 2019. 
CLERMONT, Kevin M. Standards of decision in Law. Carolina do Norte: Carolina Academic Press, 2013.

DEI VECCHI, Diego. Estándares de suficiencia probatoria, moralidad política y costos de error: el núcleo inconsistente de la epistemología jurídica de Larry Laudan. Doxa. Cuadernos de Filosofía del Derecho, v. 43, 2020.

ENGEL, Christoph. Preponderance of evidence versus intime conviction: a behavioral perspective on a conflict between american and continental european law. Vermont Law Review, v. 33, 2009.

ESSEX, Ryan; GOODMAN-DELAHUNTY, Jane. Judicial directions and the criminal standard of proof: improving juror comprehension. Journal of Judicial Administration, v. 24, n. 2, dez.-2014.

FANTL, Jeremy; MCGRATH, Matthew. Evidence, pragmatics and justification. The Philosophical Review, v. 111, n. 1, jan.-2002.

FERRER BELTRÁN, Jordi. La prueba es libertad, pero no tanto: una teoria de la prueba cuasibenthamiana. In: VÁZQUEZ, Carmen (coord). Estandáres de prueba y prueba científica - ensayos de epistemología jurídica. Madri: Marcial Pons, 2013. . La valoración racional de la prueba. Madri: Marcial Pons, 2007 . Prueba y verdad en el derecho. $2^{\mathrm{a}}$ ed. Madri: Marcial Pons, 2005.

. Sobre el deber de motivación de las decisiones probatorias y el juicio por jurados. La sentencia V.R.P., V.P.C. y otros vs. Nicaragua de la corte IDH. Quaestio facti. Revista Internacional sobre Razonamiento Probatorio, v. 1, 2020.

FERRER BELTRÁN, Jordi; TUZET, Giovanni. Sulla necessità degli standard di prova per la giustificazione delle decisioni giudiziali. Diritto \& Questione Pubbliche, n. 2, dez.2018.

GASCÓN ABELLÁN, Marina. Sobre la posibilidad de formular estándares de prueba objetivos. Doxa, Cuadernos de Filosofía del Derecho, n. 28, 2005.

GONZÁLEZ LAGIER, Daniel. ¿Es posible formular un estándar de prueba preciso y objetivo?

Algunas dudas desde un enfoque argumentativo de la prueba. Disponível em: https://www.academia.edu/37549075/_Es_posible_formular_un_est\%C3\%A1ndar_d 
e_prueba_preciso_y_objetivo_Algunas_dudas_desde_un_enfoque_argumentativo_de _la_prueba, acessado em 22 de novembro de 2019.

GUERRA, Marcelo Lima. Prova Judicial: uma Introdução. Fortaleza: Boulesis Editora. Edição do Kindle, 2016.

HAACK, Susan. Evidence matters: Science, proof and truth in the law. Cambridge: Cambridge University Press, 2014.

HOROWITZ, Irwin. A.; KIRKPATRICK, Laird. C. A concept in search of a definition: the effects of reasonable doubt instructions on certainty of guilt standards and jury verdicts. Law and Human Behavior, v. 20, n. 6, dez.-1996.

KAGEHIRO, Dorothy K.; STANTON, W. Clark. Legal vs. quantified definitions of standards of proof. Law and Human Behavior, v. 9, n. 2, 1985.

KERR, Norbert; ATKIN, Robert S.; STASSER, Garold; MEEK, David; HOLT, Robert W.; DAVIS, James H. Guilt beyond reasonable doubt: effects of concept definition and assigned decision rule on the judgments of mock jurors. Journal of Personality and Social Psychology, v. 34, n. 2, 1976.

KNIJNIK, Danilo. A prova nos juízos cível, penal e tributário. Rio de Janeiro: Forense, 2007.

LAUDAN, Larry. Is it finally time to put "proof beyond reasonable doubt" out to pasture? The Routledge Companion to Philosophy of Law Routledge, 21 de março de 2012, disponível em: https://www.routledgehandbooks.com/doi/10.4324/9780203124352.ch21, acessado em 12 de novembro de 2019.

. Por qué un estándar de prueba subjetivo y ambiguo no es un estándar. Doxa, Cuadernos de Filosofía del Derecho, n. 28, 2005.

. Verdad, error y proceso penal: un ensayo sobre epistemología jurídica. Tradução de Carmen Vázquez e Edgar Aguilera. Madri: Marcial Pons, 2013.

LIMA, Matheus Carneiro. Standards de prova no direito brasileiro. Dissertação de mestrado. São Paulo: USP, 2018.

LOEVINGER, Lee. Standards of proof in Science and law. Jurimetrics, v. 32, n. 32, 1992.

LUCCA, Rodrigo Ramina de. O dever de motivação das decisões judiciais. Salvador: Juspodivm, 2015. 
MELIM, Mafalda. Standards de prova e grau de convicção do julgador. Revista de concorrência e regulação, n. 16, out./dez.-2013.

MIRANDA NETTO, Fernando Gama de. Ônus da prova no direito processual público. Rio de Janeiro: Lumen Juris, 2009.

MIRANDA NETTO, Fernando Gama de; LEAL, Stela Tannure; SOUZA, Thiago Serrano P. Responsabilidade Civil em virtude de doenças associadas ao tabagismo. Revista Científica Virtual da ESA, v. 17, 2014.

MOTTA, Cristina Reindolff da. A motivação das decisões cíveis. Porto Alegre: Livraria do Advogado, 2012.

NIEVA FENOLL, Jordi. Carga de la prueba y estándares de prueba: dos reminiscencias del pasado. InDret, n. 3, 2020, disponível em: https://indret.com/carga-de-la-prueba-yestandares-de-prueba-dos-reminiscencias-del-pasado/, acessado em 18 de agosto de 2020 .

La valoración racional de la prueba. Madri: Marcial Pons, 2010.

NOJIRI, Sérgio. O dever de fundamentar as decisões judiciais. São Paulo: RT, 1998.

PARDO, Michael. Estándares de prueba y teoria de la prueba. In: VÁZQUEZ, Carmen (coord). Estandáres de prueba y prueba científica - ensayos de epistemología jurídica. Madri: Marcial Pons, 2013.

PEIXOTO, Ravi. Standards probatórios no direito processual brasileiro. Salvador: Juspodivm, 2021.

PEREIRA, Carlos Frederico Bastos. Fundamentação das decisões judiciais. São Paulo: RT, 2019.

PICINALI, Federico. The threshold lies in the method: Instructing jurors about reasoning beyond reasonable doubt. The International Journal of Evidence \& Proof, v. 19, n. 3, 2015 .

POLI, Roberto. Standard of proof in Italy. . In: TICHÝ, Luboš (ed.). Standard of proof in Europe. Tübingen: Mohr Siebeck, 2019.

REYES MOLINA, Sebastián. Presunción de inocencia y estándar de prueba en el proceso penal: reflexiones sobre el caso chileno. Revista de Derecho, v. XXV, n. 2, dez.-2012. SAKS, Michael J.; SPELLMAN, Barbara A. The psychological foundations of evidence law. Nova Iorque: New York University Press, 2016. 
SANTOS, Moacyr Amaral. Comentários ao código de processo civil. $6^{\mathrm{a}}$ ed. Rio de Janeiro: Forense, 1994, v. IV.

SCHMITZ, Leonardo Ziesemer. Fundamentação das decisões judiciais. São Paulo: RT, 2015.

SCHWEIZER, Mark. Standard of proof as decision threshold. In: TICHÝ, Luboš (ed.). Standard of proof in Europe. Tübingen: Mohr Siebeck, 2019.

SILVA, Beclaute Oliveira. A garantia fundamental à motivação da decisão judicial. Salvador: Juspodivm, 2007.

SILVEIRA, Daniel Coutinho da. Prova, argumento e decisão: critérios de suficiência para orientação dos juízos de fato no direito processual brasileiro. Dissertação de Mestrado. São Paulo: USP, 2011.

SOBA BRACESCO, Ignacio M.. La predeterminación normativa de los estándares de prueba (um derivado de la seguridade jurídica). Revista Eletrônica de Direito Processual-REDP, v. 21, n. 2, mai./ago.-2020, disponível em: www.redp.uerj.br, acessado em 10 de maio de 2020.

SOLAN, Lawrence. Refocusing the burden of proof in criminal cases: some doubt about reasonable doubt. Texas Law Review, v. 78, 1999.

STRECK, Lenio Luiz. O que é isto - decido conforme minha consciência? Porto Alegre: Livraria do Advogado, 2012.

TRENTO, Simone. Os standards e o ônus da prova: suas relações e causas da variação. Revista de Processo. São Paulo: RT, n. 226, dez.-2013.

TUZET, Giovanni. Assessment criteria or standards of proof? An effort in clarification. Artificial Intelligence and Law, out.-2018.

TWINING, William; SCHUM, David; ANDERSON, Terence. Analysis of evidence. $2^{\mathrm{a}}$ ed. Cambridge: Cambridge University Press, 2005.

UBERTIS, Giulio. Fatto, prova e verità (alla luce del principio dell'oltre ogni ragionevole dubbio). Criminalia, 2009.

VÁZQUEZ, Carmen. A modo de presentación. In: VÁZQUEZ, Carmen (coord). Estandáres de prueba y prueba científica - ensayos de epistemología jurídica. Madri: Marcial Pons, 2013. 
Revista Eletrônica de Direito Processual - REDP.

Rio de Janeiro. Ano 15. Volume 22. Número 2. Maio a Agosto de 2021

Periódico Quadrimestral da Pós-Graduação Stricto Sensu em Direito Processual da UERJ

Patrono: José Carlos Barbosa Moreira (in mem.). ISSN 1982-7636. pp. 586-618 www.redp.uerj.br

VIALE DE GIL, Paula A.. ¿La prueba es suficiente cuando es suficiente? Aproximación a la construcción de la decisión de suficiencia de la prueba en materia penal Revista Pensar em Derecho, n. 4, 2014, disponível em: http://www.derecho.uba.ar/publicaciones/pensar-en-derecho/revista-4.php, acessado em 29 de dezembro de 2019.

ZUCKERMAN, Adrian; ROBERTS, Paul. Criminal evidence. Oxford: Oxford University Press, 2004. 